Provided for non-commercial research and education use. Not for reproduction, distribution or commercial use.

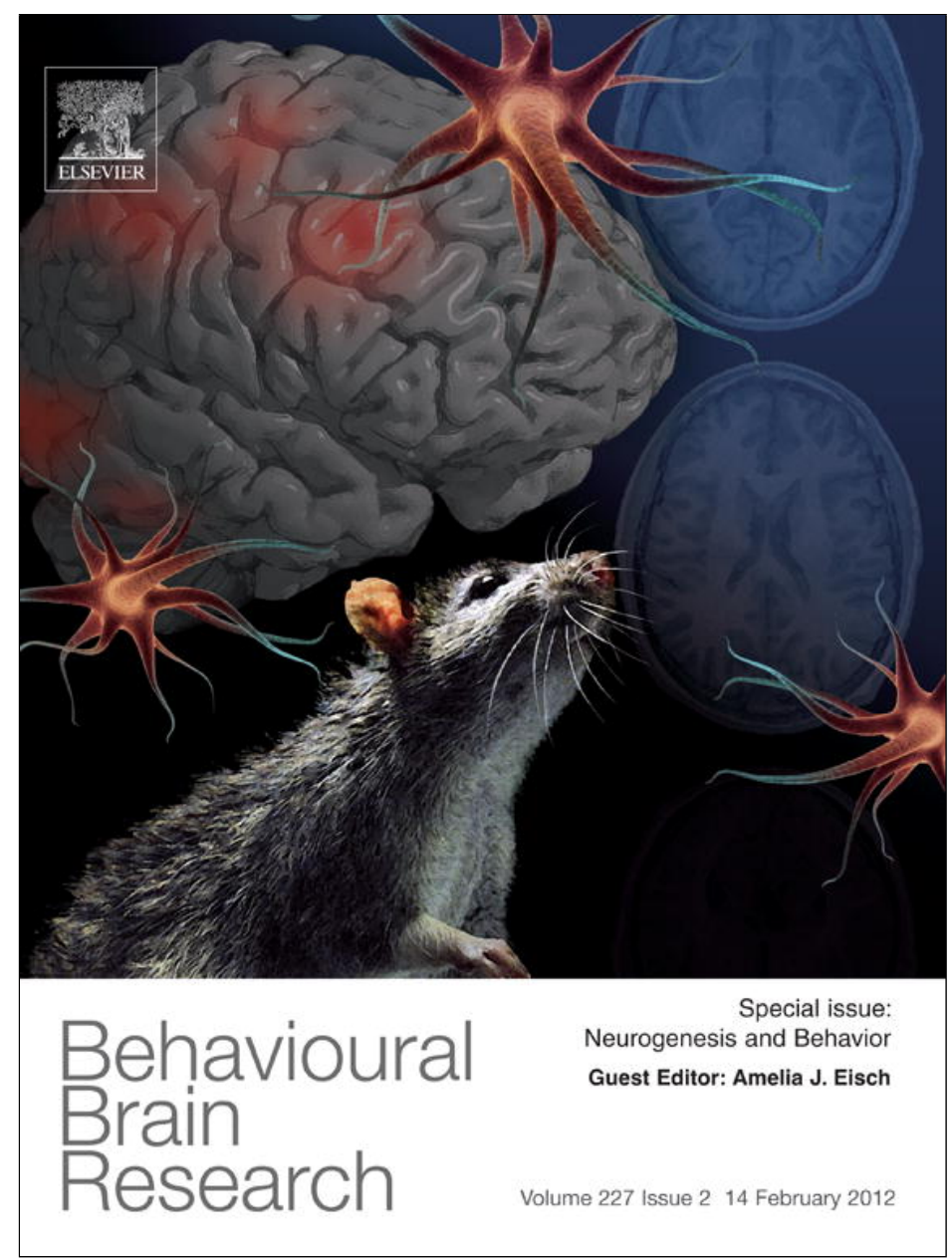

This article appeared in a journal published by Elsevier. The attached copy is furnished to the author for internal non-commercial research and education use, including for instruction at the authors institution and sharing with colleagues.

Other uses, including reproduction and distribution, or selling or licensing copies, or posting to personal, institutional or third party websites are prohibited.

In most cases authors are permitted to post their version of the article (e.g. in Word or Tex form) to their personal website or institutional repository. Authors requiring further information regarding Elsevier's archiving and manuscript policies are encouraged to visit:

http://www.elsevier.com/copyright 
Research report

\title{
Depressive-like behaviour of mice lacking cellular prion protein
}

\author{
Vinicius M. Gadotti, Stephan P. Bonfield, Gerald W. Zamponi*,1 \\ Department of Physiology and Pharmacology, Hotchkiss Brain Institute, University of Calgary, Calgary T2N 4N1, Canada
}

\section{A R T I C L E I N F O}

\section{Article history:}

Received 11 September 2010

Received in revised form 23 February 2011

Accepted 4 March 2011

Available online 23 March 2011

\section{Keywords:}

Prion protein

Depression

Knockout mice

Forced swimming test

Tail suspension test

Nmda receptor

\begin{abstract}
A B S T R A C T
Cellular Prion Protein $\left(\mathrm{PrP}^{\mathrm{C}}\right)$ is known to mediate a protective role in several neurological conditions such as ischemia and epilepsy. However, so far, little information is available concerning the role of $\mathrm{PrP}^{\mathrm{C}}$ in psychiatric disorders such as depression. Here, we have used $\operatorname{PrP}^{\mathrm{C}}$ null mice to examine a putative role of $\mathrm{PrP}^{\mathrm{C}}$ in depressive-like states. Prion protein null mice exhibited depressive-like behaviour when compared to wild-type mice in both the Forced Swimming Test (FST) and Tail Suspension Test (TST). The clinical antidepressant drug imipramine and the NMDA receptor antagonist MK-801 reversed the depressive-like behaviour observed for knockout mice in the TST. The present data thus indicate that $\mathrm{PrPC}^{\mathrm{C}}$ exerts a critical role in modulating the depressive-like state in mice, reinforcing the notion that $\mathrm{PrP}^{\mathrm{C}}$ might be associated with alterations in mood disorder states, and suggests a possible role of $\operatorname{PrP}^{\mathrm{C}}$ as a potential drug target for treating depressive disorders.
\end{abstract}

(c) 2011 Elsevier B.V. All rights reserved.

\section{Introduction}

Depression is a common, recurring psychiatric disorder that ranges in severity from mild to very severe. The attendant economic costs to society and personal burden to patients and families are enormous. The World Health Organization estimates that major depression is now the fourth most important cause worldwide of loss in disability-adjusted life-years and will be the second most important cause by 2020 [24]. Although pharmaco-therapy of depression includes a battery of drugs, the efficacies of those drugs are unsatisfactory, because they exert multiple unwanted side effects and their antidepressant mechanism remains incompletely understood [23]. However, it is clear that dysfunction of the brain monoamine circuitry in the limbic system (e.g., serotonin (5-HT), dopamine (DA) and noradrenaline (NA)) is likely to play a role in the pathophysiology of depressive disorders [36]. Moreover, recent evidence has linked other hippocampal neurotransmitters, such as glutamate, to the pathogenesis of depression [14].

Prions are proteinaceous infectious agents that play important role in the ethiology of transmissible spongiform encephalopathies (TSEs). These disorders arise from a progressive conversion of the normal, non pathological cellular prion protein $\left(\operatorname{PrP}^{\mathrm{C}}\right)$ into a misfolded, infectious scrapie form (PrPSC) that is neurotoxic. While the role of $\operatorname{PrPSC}$ in TSEs is well established, less is known about

\footnotetext{
* Corresponding author. Tel.: +1 403220 8687; fax: +1 4032108106.

E-mail address: zamponi@ucalgary.ca (G.W. Zamponi).

1 Scientist of the Alberta Heritage Foundation for Medical Research and a Canada Research Chair in Molecular Neurobiology.
}

the physiological role of $\operatorname{PrP}^{\mathrm{C}}$, a protein that is widely expressed in the brain and other tissues [for review see 37]. Our laboratory has recently shown that the absence of $\operatorname{PrPC}^{\mathrm{C}}$ alters N-Methyl-DAspartate (NMDA) receptor function in hippocampal neurons [15], and hence, we hypothesized that $\operatorname{PrP}^{\mathrm{C}}$ might regulate depressivelike behavior by virtue of altered NMDA receptor activity in the hippocampus. Indeed, there are several collorary lines of investigations that suggest possible links between prion proteins and depression. For example, Weis et al. [35] recently showed that $\operatorname{Pr}^{\mathrm{C}_{-}}$ positive glial cells were significantly reduced in cingulate gyrus white matter of bipolar disorder and patients and major depression patients. Moreover, there appears to be comorbidity between prion diseases such as Creutzfeld-Jacob disease and depression as shown by several case reports $[9,12,13,34]$.

The aim of the present study was to investigate the response of $\mathrm{PrP}^{\mathrm{C}}$ null mice in well-established behavioural models that predict depressive activity, such as the Forced Swimming Test (FST) and the Tail Suspension Test (TST). Here, we show that $\operatorname{PrP}^{C}$-null mice exhibit depressive-like behaviour in these tests, and that this behaviour can be reversed by a classical tricyclic antidepressant or by an NMDA receptor antagonist.

\section{Materials and methods}

\subsection{Animals}

All experiments were conducted following the protocol approved by the Institutional Animal Care and Use Committee (protocol \#M09099) and all efforts were made to minimize animal suffering. A total of 125 adult male C57BL/6J (wild type and PrP null mice 10 weeks old, weighing 25-30 g) were used. Animals were housed in a maximum number of five per cage $(30 \mathrm{~cm} \times 20 \mathrm{~cm} \times 15 \mathrm{~cm})$ with food and water 

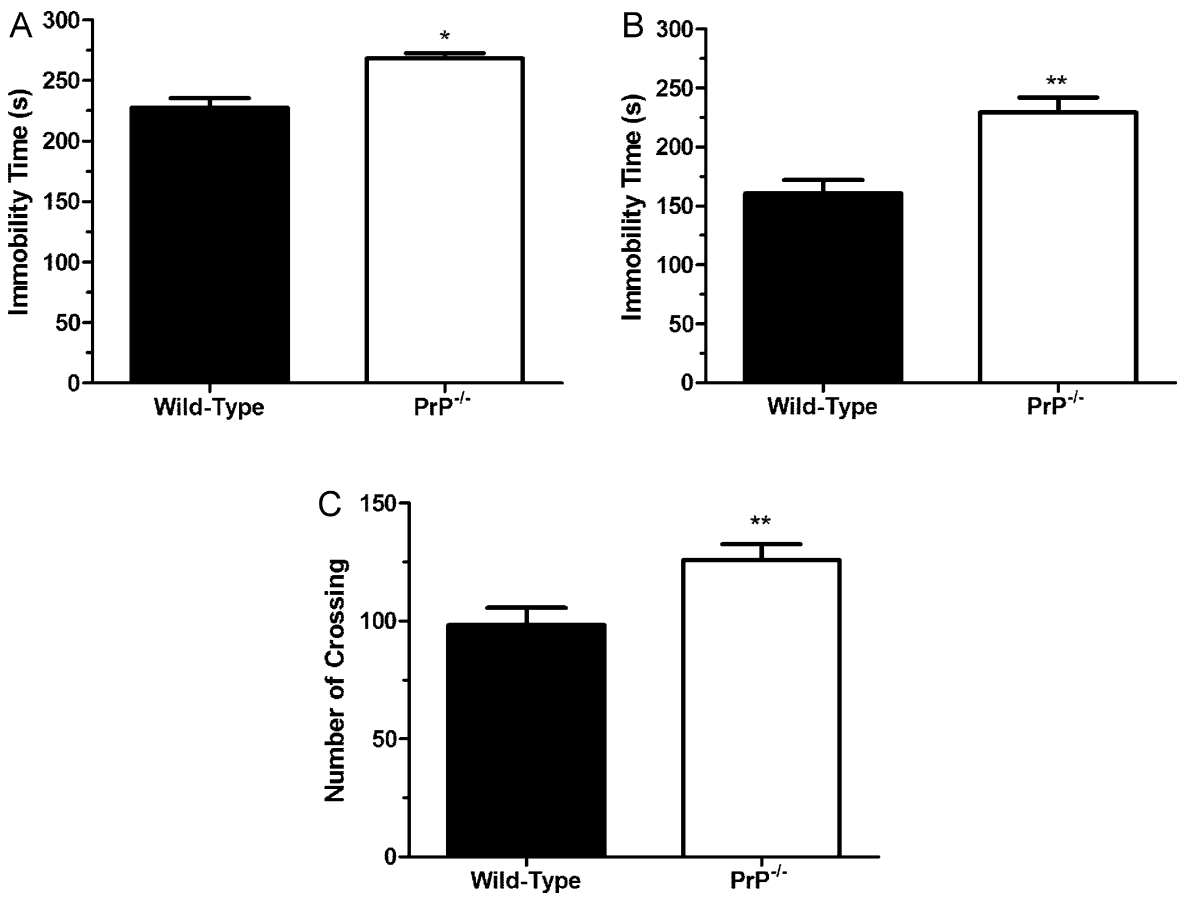

Fig. 1. Immobility time of wild type or PrPC null mice in the FST (panel A) and in the TST (panel B) and number of crossing in the open-field test (panel C). Each column represents the mean + S.E.M. $(n=5-7) .{ }^{*} P<0.05,{ }^{* *} P<0.01$ as compared with the control (wild-type) group.

ad libitum. They were kept in $12 \mathrm{~h} \mathrm{light/dark} \mathrm{cycles} \mathrm{(lights} \mathrm{on} \mathrm{at} \mathrm{7:00} \mathrm{a.m.)} \mathrm{at} \mathrm{a} \mathrm{tem-}$ perature of $23 \pm 1^{\circ} \mathrm{C}$. All manipulations were carried out between $11.00 \mathrm{a}$.m. and 3:00 p.m. Separate cohorts of mice were used for each test and each mouse was used only once. The observers were blind to the experimental conditions. Mice with a targeted disruption of the prion gene (PrP) of the Zürich 1 strain [5] were obtained from the European Mouse Mutant Archive (EM:0158; European Mouse Mutant Archive Rome) and out-bred to generate $\operatorname{PrP}^{-1-}$ (PrP-null) littermates used in the experiments. Genotyping was performed by gel electrophoresis of PCR products obtained from genomic DNA that was isolated from tail samples. Primers and PCR parameters were similar to those used previously [5].

\subsection{Drugs and treatment}

The following drugs were used in the study: Imipramine and MK-801 (Sigma Chemical Company, St. Louis, MO, USA). All drugs were dissolved in PBS and administered by intraperitoneal (i.p.) route (30 min before TST, FST or OF) in a constant volume of $10 \mathrm{ml} / \mathrm{kg}$ body weight. Appropriate vehicle-treated groups were also assessed simultaneously.

\subsection{Forced swimming test (FST)}

Mice were individually forced to swim in an open cylindrical container (diameter $10 \mathrm{~cm}$, height $25 \mathrm{~cm}$ ), containing $19 \mathrm{~cm}$ of water at $25 \pm 1^{\circ} \mathrm{C}$; the total duration of immobility during a 6 min test was scored as described previously [28]. Each mouse was judged to be immobile when it ceased moving its limbs in any kind of swimming action and remained motionless floating in the water, while making the necessary movements to keep its head above water. Immobility time was measured for C57BL/6J wild type and $\mathrm{PrP}^{-1-}$ mice for the entire 6 min they spent in the water in order to evaluate depressive-like behaviour.

\subsection{Tail suspension test (TST)}

The total duration of immobility induced by tail suspension was measured according to the method described by Steru et al. [32] with minor modifications. Briefly, mice were both acoustically and visually isolated and suspended $50 \mathrm{~cm}$ above the floor by adhesive tape placed approximately $1 \mathrm{~cm}$ from the tip of the tail. Immobility times in the C57BL/6J wild type and $\mathrm{PrP}^{-1-}$ mice were scored visually and recorded manually with a chronometer for $6 \mathrm{~min}$ in order to evaluate depressivelike behaviour. Each mouse was judged to be immobile when it ceased struggling and remained without any body movement (total immobility time). A decrease in the duration of immobility is indicative of an antidepressant-like effect. Mice were treated with imipramine $(10 \mathrm{mg} / \mathrm{kg}$, i.p.), or MK-801 $(0.01 \mathrm{mg} / \mathrm{kg}$, i.p.), or with vehicle (PBS, $10 \mathrm{ml} / \mathrm{kg}$, i.p.) $30 \mathrm{~min}$ before each tail suspension experiment was carried out. We chose the TST rather than FST for drug studies because of the larger depressive effect observed with the $\mathrm{PrP}^{-1-}$ mice in the TST.

\subsection{Open-field test}

Ambulatory behaviour was assessed in an open-field test as described previously [4]. The apparatus consisted of a wooden box measuring $40 \mathrm{~cm} \times 60 \mathrm{~cm} \times 50 \mathrm{~cm}$ with a frontal glass wall. The floor of the arena was divided into 12 equal squares and placed in a quiet room. The test room was illuminated with soft white light. Animals were placed in the rear left square of the wooden box and were left to left to explore the 12 squares freely for $6 \mathrm{~min}$, during which time the experimenter counted the number of squares that the animal had crossed with all of its paws. Mice were treated with imipramine $(10 \mathrm{mg} / \mathrm{kg}$, i.p.) or MK-801 $(0.01 \mathrm{mg} / \mathrm{kg}$, i.p.) or with vehicle (PBS, $10 \mathrm{ml} / \mathrm{kg}$, i.p.) $30 \mathrm{~min}$ prior to each evaluation. After each individual experiment, the apparatus was cleaned with a 70\% alcohol solution and dried.

\subsection{Statistical analysis}

Data were presented as means \pm SEM and evaluated by t-tests or two-way analysis of variance (ANOVA) followed by a Duncan test when appropriate. A value of $P<0.05$ was considered to be significant.

\section{Results}

\subsection{Depressive-like behaviour of $\mathrm{PrP}^{-/-}$mice in the FST and TST}

The results depicted in Fig. 1 show the behavioural responses of wild type mice and mice lacking $\operatorname{PrP}^{\mathrm{C}}$ when assessed in both FST and TST. As shown in Fig. 1, PrP $^{-1-}$ mice exhibited a significantly elevated immobility time in both the FST (panel A) and in the TST (panel B) compared to their wild type littermates, (t-test). Of particular note, in the open-field test we found that there was a significantly higher number of crossings of $\mathrm{PrP}^{-1-}$ mice compared to the expected normal ambulatory behaviour of the wild type animals (Fig. 1C). These data show that depressive-like behaviour of $\mathrm{PrP}^{-/-}$mice in these tests was not due to an unspecific effect of the gene knockdown, such as impairment of locomotor activity.

\subsection{Effect of imipramine on mice depressive-like state in the TST}

We then assessed whether a classical antidepressant drug could reverse the depressive-like behaviour observed for $\operatorname{PrP}^{-1-}$ mice in the TST. Fig. 2 shows that the administration of imipramine $(10 \mathrm{mg} / \mathrm{kg}$, i.p., a tryciclic antidepressant) $30 \mathrm{~min}$ before the TST 


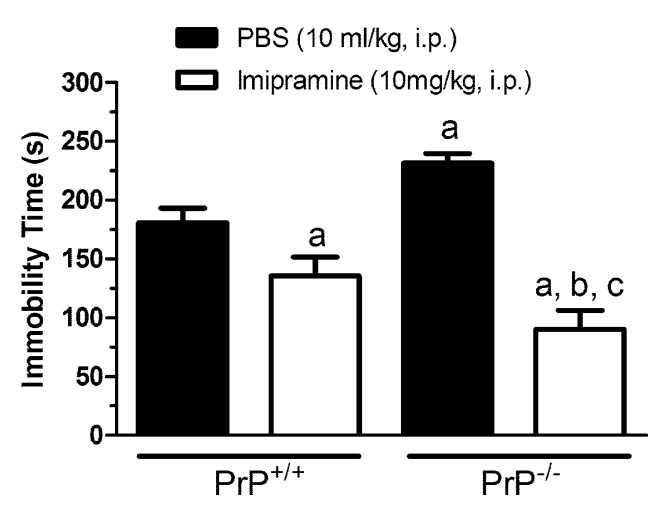

Fig. 2. Effect of pretreatment with imipramine $(10 \mathrm{mg} / \mathrm{kg}$, i.p. $)$ on the depressivelike behaviour of mice in the TST. Each column represents the mean+S.E.M. $(n=6-7)$. ${ }^{\text {a }} P<0.05$ compared with the control group (PBS treated wild-type mice). ${ }^{\mathrm{b}} P<0.001$ when compared with $\mathrm{PBS}$ treated $\operatorname{PrP}^{\mathrm{C}}$ null mice. ${ }^{\mathrm{C}} P<0.01$ compared with imipramine treated wild-type mice.

decreases the immobility time in both wild-type mice and $\mathrm{PrP}^{-/-}$ mice. The two-way ANOVA revealed a significant effect of genotype $[F(1,21)=74.29, P<0.01]$, treatment $[F(1,21)=1.66, P=0.21]$ and the genotype $\mathrm{X}$-treatment interaction $[F(1,21)=27.43, P<0.01]$. Therefore, these data demonstrate that the behaviour observed in Fig. 1 indeed bears the standard characteristics of depression (i.e. prolonged immobility, apathy, decreased effort to swim) rather than immobilization caused by motor deficits.

\subsection{Effect of MK-801 on wild-type and $\operatorname{PrP}^{-/-}$mice in the TST}

To determine if a mechanism involving NMDA-receptor activity may be involved in the depressive-like behaviour exhibited by $\mathrm{PrP}^{-1-}$ mice in the TST, we delivered the NMDA receptor antagonist MK-801 through an i.p. route to both wild-type and $\mathrm{PrP}^{-1-}$ mice. Fig. 3 shows that the administration of MK-801 (0.01 mg/kg, i.p.) $30 \mathrm{~min}$ before the TST decreases the immobility time in wild-type mice and $\mathrm{PrP}^{-1-}$ mice. The two-way ANOVA revealed a significant effect of genotype $[F(1,320)=11.7, P=0.018]$, the treatment $[F(4,54)=11.5 P=0.03]$ and the genotype $\mathrm{X}$-treatment interaction $[F(2,01)=7.7, P<0.001]$. The MK-801 mediated reversal of the depressive like state seen in PrP null mice is consistent with observations that NMDA receptor activity is upregulated in the absence of $\operatorname{PrPC}^{\mathrm{C}}[16]$, and provides a functional link between this NMDA receptor activity and altered behavioural states.

\subsection{Effects of Imipramine or MK-801 on spontaneous locomotor activity of wild-type and $\mathrm{PrP}^{-/-}$mice}

Imipramine and MK-801 were tested in the locomotor activity apparatus in order to test whether the variation in the immobil-

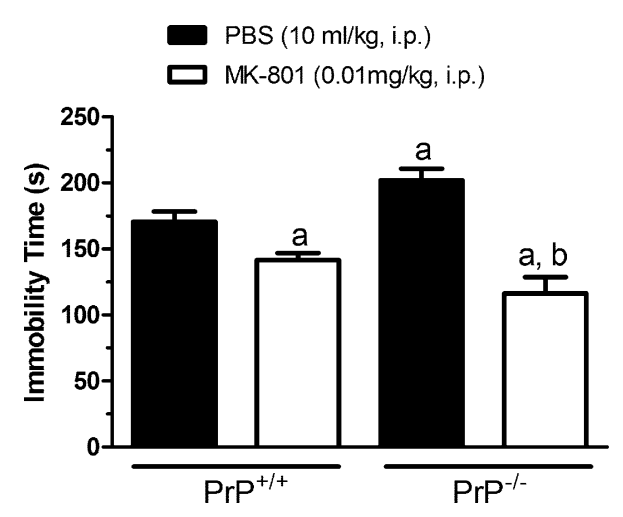

Fig. 3. Effect of pretreatment with MK-801(0.01 mg/kg, i.p.) on the depressive-like behaviour of mice in the TST. Each column represents the mean + S.E.M. $(n=6-11)$. ${ }^{\mathrm{a}} P<0.05$ compared with the control group (PBS treated wild-type mice). ${ }^{\mathrm{b}} P<0.001$ when compared with $\mathrm{PBS}$ treated $\mathrm{PrP}^{\mathrm{C}}$ null mice.

ity time evaluated in the tail suspension test could be linked to a modification of the spontaneous locomotor activity rather than an antidepressant-like effect of the drugs. The results presented in Fig. 4 show that the administration of imipramine or MK-801 did not produce any effect in the ambulatory behaviour of wild-type (Fig. 4a) or $\mathrm{PrP}^{-1-}$ (Fig. 4b) animals.

\section{Discussion}

It is becoming increasingly clear that cellular prion protein is an important neuromodulator [37], but there have been few studies showing its possible role in mood disorders. Our data demonstrate that the $\mathrm{PrP}^{-1-}$ mice exhibit an increase in immobility time compared to wild-type mice in both the FST and in the TST. Both of these tests have been developed to evaluate depressive-like behaviours in rodents and their usefulness is based on the observation that immobility time is reduced by many different classes of antidepressants $[3,28]$. Although these tests are typically employed to screen for new antidepressant drugs [8], they have been widely used to investigate depressive-like behaviour that may also be induced by drugs $[7,26]$ or by gene knock-down $[2,11]$. It is important to emphasize that the depressive-like behaviour of $\operatorname{PrP}^{-1-}$ mice in these tests was not due to motor dysfunction, as a general increase of ambulatory activity was observed for $\mathrm{PrP}^{-1-}$ mice in the open-field test. It is interesting to note that a previous study from Lobao-Soares et al. [18] did not report a statistical difference in the number of crossings (ambulatory behaviour) of $\mathrm{PrP}^{-1-}$ mice in the open-field test. Also of interest, and in agreement with our results, are the observations by Nico et al. [25] that show a decrease in the swimming time of $\mathrm{PrP}^{-1-}$ mice in which the authors used the FST as an acute stress protocol.
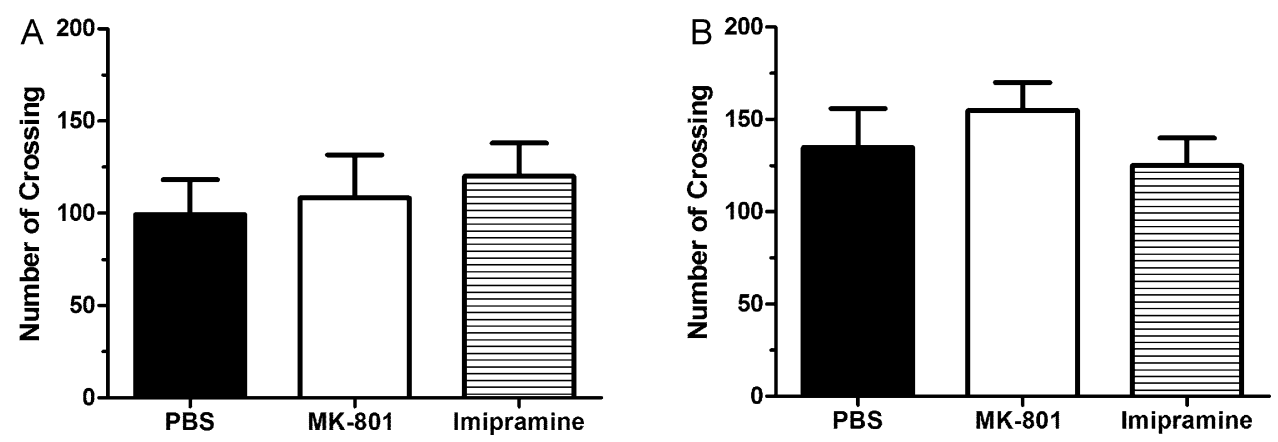

Fig. 4. Effect of the pretreatment of mice with MK-801 (0.01 mg/kg, i.p.) or Imipramine $(10 \mathrm{mg} / \mathrm{kg}$, i.p.) on the number of crossings in the open-field test for wild type (panel A) and $\mathrm{PrP}^{-1-}$ (panel B) mice. Each column represents the mean +S.E.M. $(n=5-6)$. 
In our hands, the tricyclic antidepressant imipramine was able to reverse the depressive-like behaviour observed for $\operatorname{PrP}^{-1-}$ mice. The efficacy of this antidepressant to decrease the immobility time was greater in $\mathrm{PrP}^{-1-}$ mice than the effect observed for wild-type mice. Results from Klingenstein et al. [16] indicate that tryciclic antidepressants display structure-dependent antiprion effects, and enhanced the antiprion effects of quinacrine in a cell culture model of prion disease. The ability of imipramine to decrease in vivo immobility is likely unrelated to its in vitro antiprion effects.

Glutamate is the excitatory neurotransmitter controlling synaptic excitability and plasticity in most brain circuits, including those areas thought to be involved in depression such as the hippocampus and the amygdala [27]. The NMDA receptor is one of the major ionotropic glutamate receptors, and its known role in depression together with our previous findings showing that $\operatorname{PrP}^{\mathrm{C}}$ controls NMDA receptor activity in the hippocampus [15] led us to investigate the involvement of this receptor in the depressivelike behaviour of $\mathrm{PrP}^{\mathrm{C}}$ null mice. NMDA receptor antagonists have been proposed as potential antidepressants and reportedly exhibit antidepressant effects in both humans [10,19,21] and rodents $[17,22,29]$. It is important to note that even conventional antidepressants that act through the monoaminergic system may ultimately signal to NMDA receptors, thus leading to the same functional effects as NMDA antagonists [31].

There is now a growing body of scientific literature describing the involvement of the hippocampus in the neurobiology of such mood disorders, mainly based on observations that similar neurochemical and morphological changes can be found in the hippocampus of both depressed humans and stress-induced depressed animals, and these changes can be prevented and/or reversed by antidepressant treatment $[6,20,30,33]$. Impairment of neuroplasticity in the hippocampus, amygdala and cortex is hypothesized to be the mechanism by which cognitive function, learning, memory and emotions are altered in depression [20]. While much attention has been focused on hippocampal serotonergic and noradrenergic systems, recent evidence has linked other hippocampal neurotransmitters, such as glutamate and nitric oxide (NO) to behavioural changes induced by stress and subsequently observed in depressed animals [14]. Furthermore, several studies indicate that there is a disproportionate amount of serotonin dysregulation in prion diseases and that prion-mediated cytotoxicity may be blocked by NMDA receptor antagonists [for review see 1]. In this context, our findings fit nicely with our previous work showing augmented NMDA receptor function in hippocampal neurons of $\mathrm{PrP}^{-1-}$ mice [15].

In summary, results from the present study show, for the first time, that $\operatorname{PrP}^{\mathrm{C}}$ plays a role in depression through a mechanism that is consistent with an inhibition of the glutamatergic system through NMDA receptors. This in turn may suggest a molecular mechanism underlying the well-established co-morbidity between early onset Creutzfeldt-Jakob disease and depression $[9,12,13,34]$.

\section{Competing interests}

The authors declare that they have no competing interests.

\section{Author contribution}

VMG designed and performed experiments, data analysis and wrote the article. SPB performed experiments and edited the manuscript. GWZ supervised the research project and edited the manuscript. The authors read and approved the final manuscript.

\section{Acknowledgments}

This work was supported by an operating grant to GWZ from the PrioNet Canada. GWZ is a Scientist of the Alberta Heritage Foundation for Medical Research (AHFMR) and a Canada Research Chair in Molecular Neurobiology. VMG is supported by an AHFMR Fellowship and by a Fellowship from the Hotchkiss Brain Institute (HBI). We thank Dr. Clint Doering for genotyping and breeding paradigms, and Dr. Frank R. Jirik for providing the outbred PrP null mouse line.

\section{References}

[1] Appleby BS. Psychotropic medications and the treatment of human prion diseases. CNS Neurol Disord Drug Targets 2009;8:353-62.

[2] Bhatnagar S, Nowak N, Babich L, Bok L. Deletion of the 5-HT3 receptor differentially affects behavior of males and females in the Porsolt forced swim and defensive withdrawal tests. Behav Brain Res 2004;153:527-35.

[3] Borsini F. Role of the serotonergic system in the forced swimming test. Neurosci Biobehav Rev 1995;19:377-95.

[4] Budni J, Gadotti VM, Kaster MP, Santos AR, Rodrigues AL. Role of different types of potassium channels in the antidepressant-like effect of agmatine in the mouse forced swimming test. Eur J Pharmacol 2007;575:87-93.

[5] Bueler H, Fischer M, Lang Y, Bluethmann H, Lipp HP, DeArmond SJ, et al. Normal development and behaviour of mice lacking the neuronal cell-surface PrP protein. Nature 1992;356:577-82.

[6] Campbell S, Marriott M, Nahmias C, MacQueen GM. Lower hippocampal volume in patients suffering from depression: a meta-analysis. Am J Psychiatry 2004;161:598-607.

[7] Cryan JF, Hoyer D, Markou A. Withdrawal from chronic amphetamine induces depressive-like behavioral effects in rodents. Biol Psychiatry 2003;54:49-58.

[8] Cryan JF, Markou A, Lucki I. Assessing antidepressant activity in rodents: recent developments and future needs. Trends Pharmacol Sci 2002;23:238-45.

[9] Cumbler E, Furfari K, Guerrasio J. Creutzfeldt-Jakob disease presenting as severe depression: a case report. Cases J 2009;2:122.

[10] Diazgranados N, Ibrahim L, Brutsche NE, Newberg A, Kronstein P, Khalife $\mathrm{S}$, et al. A randomized add-on trial of an N-methyl-D-aspartate antagonist in treatment-resistant bipolar depression. Arch Gen Psychiatry 2010;67:793-802.

[11] El Yacoubi M, Ledent C, Parmentier M, Bertorelli R, Ongini E, Costentin J, et al. Adenosine A2A receptor antagonists are potential antidepressants: evidence based on pharmacology A2A receptor knockout mice. Br J Pharmacol 2001;134:68-77.

[12] Jardri R, DiPaola C, Lajugie C, Thomas P, Goeb JL. Depressive disorder with psychotic symptoms as psychiatric presentation of sporadic Creutzfeldt-Jakob disease: a case report. Gen Hosp Psychiatry 2006;28:452-4.

[13] Jiang TT, Moses H, Gordon H, Obah E. Sporadic Creutzfeldt-Jakob disease presenting as major depression. South Med J 1999;92:807-8.

[14] Joca SR, Ferreira FR, Guimarães FS. Modulation of stress consequences by hippocampal monoaminergic, glutamatergic and nitrergic neurotransmitter systems. Stress 2007;10:227-49.

[15] Khosravani H, Zhang Y, Tsutsui S, Hameed S, Altier C, Hamid J, et al. Prion protein attenuates excitotoxicity by inhibiting NMDA receptors. J Cell Biol 2008;181:551-65.

[16] Klingenstein R, Löber S, Kujala P, Godsave S, Leliveld SR, Gmeiner P, et al. Tricyclic antidepressants, quinacrine and a novel, synthetic chimera thereof clear prions by destabilizing detergent-resistant membrane compartments. J Neurochem 2006;98:748-59.

[17] Kos T, Legutko B, Danysz W, Samoriski G, Popik P. Enhancement of antidepressant-like effects but not brain-derived neurotrophic factor mRNA expression by the novel $\mathrm{N}$-methyl-D-aspartate receptor antagonist neramexane in mice. J Pharmacol Exp Ther 2006;318:1128-36.

[18] Lobão-Soares B, Walz R, Carlotti Jr CG, Sakamoto AC, Calvo F, Terzian AL, et al. Cellular prion protein regulates the motor behaviour performance and anxiety-induced responses in genetically modified mice. Behav Brain Res 2007:183:87-94.

[19] Machado-Vieira R, Salvadore G, Diazgranados N, Zarate Jr CA. Ketamine and the next generation of antidepressants with a rapid onset of action. Pharmacol Ther 2009;123:143-50.

[20] Macqueen G, Frodl T. The hippocampus in major depression: evidence for the convergence of the bench and bedside in psychiatric research? Mol Psychiatry 2011;16:252-64.

[21] Maeng S, Zarate Jr CA. The role of glutamate in mood disorders: results from the ketamine in major depression study and the presumed cellular mechanism underlying its antidepressant effects. Curr Psychiatry Rep 2007;9:467-74.

[22] Maeng S, Zarate Jr CA, Du J, Schloesser RJ, McCammon J, Chen G, et al. Cellular mechanisms underlying the antidepressant effects of ketamine: role of alpha-amino-3-hydroxy-5-methylisoxazole-4-propionic acid receptors. Biol Psychiatry 2008;63:349-52.

[23] Murray CJ, Lopez AD. Global mortality, disability and the contribution of risk factors: Global Burden of Disease Study. Lancet 1997;349:1436-42.

[24] Murray CJ, Lopez AD. Evidence-based health policy-lessons from the Global Burden of Disease Study. Science 1996;274:740-3. 
[25] Nico PB, de-Paris F, Vinadé ER, Amaral OB, Rockenbach I, Soares BL, et al. Altered behavioural response to acute stress in mice lacking cellular prion protein. Behav Brain Res 2005;162:173-81.

[26] O'Reilly KC, Shumake J, Gonzalez-Lima F, Lane MA, Bailey SJ. Chronic administration of 13-cis-retinoic acid increases depression-related behavior in mice. Neuropsychopharmacology 2006;31:1919-27.

[27] Ozawa S, Kamiya H, Tsuzuki K. Glutamate receptors in the mammalian central nervous system. Prog Neurobiol 1998;54:581-618.

[28] Porsolt RD, Le Pichon M, Jalfre M. Depression: a new animal model sensitive to antidepressant treatments. Nature 1977;266:730-2.

[29] Réus GZ, Stringari RB, Kirsch TR, Fries GR, Kapczinski F, Roesler R, et al. Neurochemical and behavioural effects of acute and chronic memantine administration in rats: further support for NMDA as a new pharmacological target for the treatment of depression? Brain Res Bull 2010;81:585-9.

[30] Santarelli L, Saxe M, Gross C, Surget A, Battaglia F, Dulawa S, et al. Requirement of hippocampal neurogenesis for the behavioral effects of antidepressants. Science 2003;301:805-9.
[31] Skolnick P. Antidepressants for the new millennium. Eur J Pharmacol 1999;375:31-40.

[32] Steru L, Chermat R, Thierry B, Simon P. The tail suspension test: a new method for screening antidepressants in mice. Psychopharmacology 1985;85:367-70.

[33] Videbech P. Ravnkilde B. Hippocampal volume and depression: a meta-analysis of MRI studies. Am J Psychiatry 2004;161:1957-66.

[34] Wall CA, Rummans TA, Aksamit AJ, Krahn LE, Pankratz VS. Psychiatric manifestations of Creutzfeldt-Jakob disease: a 25 -year analysis. J Neuropsychiatry Clin Neurosci 2005;17:489-95.

[35] Weis S, Haybaeck J, Dulay JR, Llenos IC. Expression of cellular prion protein $(\operatorname{PrP}(\mathrm{c}))$ in schizophrenia, bipolar disorder, and depression. J Neural Transm 2008; 115:761-71

[36] Wong DT, Bymaster FP. Dual serotonin and noradrenaline uptake inhibitor class of antidepressants-potential for greater efficacy or just hype? Prog Drug Res 2002;58:169-222.

[37] Zamponi GW, Stys PK. Role of prions in neuroprotection and neurodegeneration: a mechanism involving glutamate receptors? Prion 2009;3:187-9. 